\title{
Accelerated Corrosion Fatigue Crack Growth Studies on IS 2062 Gr. E 300 Steel
}

\author{
G. Raghava \\ S. Kelita \\ Department of Civil \\ Engineering, Mepco \\ Schlenk Engineering \\ College, \\ Sivakasi - 626005 \\ Chief scientist \\ CSIR - Structural \\ Engineering Research \\ Centre, \\ Council of Scientific and \\ Industrial Reasearch \\ CSIR Campus, Taramani \\ Chennai - 600113
}

\author{
S. Vishnuvardhan \\ Scientist \\ CSIR - Structural \\ Engineering Research \\ Centre, \\ Council of Scientific and \\ Industrial Reasearch \\ CSIR Campus, Taramani \\ Chennai - 600113
}

\author{
C. Ramesh Babu \\ Assistant professor \\ Department of Civil \\ Engineering, Mepco \\ Schlenk Engineering \\ College, \\ Sivakasi - 626005
}

\begin{abstract}
Corrosion fatigue crack growth experiment was conducted on ESE(T) (Eccentrically-loaded Single Edge notch Tension) specimen made of IS 2062 steel in salt water environment. The specimen was placed in a transparent chamber made of perspex sheet containing 3.5\% NaCl solution which acted as corrosion environment. The corrosion process was accelerated by applying constant direct current of $0.2 \mathrm{~A}$ which was supplied by means of a regulated power supply. The test was conducted using a $\pm 250 \mathrm{kN}$ capacity computer controlled servo-hydraulic fatigue rated Universal Testing Machine. The maximum and minimum load values were $15 \mathrm{kN}$ and $1.5 \mathrm{kN}$. The test frequency was $0.375 \mathrm{~Hz}$ and the stress ratio was 0.1 . Number of cycles to crack initiation was determined. Crack growth data were recorded at regular intervals. Crack growth curves were plotted and material constants $C$ and $m$ were found. Analytical studies were carried out and the results were compared with experimental results. Details of the analytical and experimental studies and the results are presented in this paper.
\end{abstract}

Keywords: Fatigue crack growth, corrosion fatigue, IS 2062 Gr. E 300 steel, ESE(T) specimen, fatigue damage

\section{INTRODUCTION}

Some of the civil engineering, aerospace industry and infrastructure related structures are exposed to corrosion environment and subjected to repetitive operational loads, e.g., bridges, offshore structures, aircraft, power plant piping components. Corrosion is one of the most significant phenomena which happens for the alloys or metals used as implants in the body. Fatigue can affect the product as a whole or can cause defects in the components of the product. The coupled effects of fatigue and corrosion are more detrimental than either acting separately [1]. The maintenance, repair, and life expectancy of damaged engineering structures and machine components, issues caused by corrosion fatigue are of particular concern to both researchers and engineers. The corrosion fatigue crack growth (CFCG) rate is of great interest for the rational life prediction and the safety assessment of engineering structures. Corrosion environment significantly decreases the fatigue strength and life. In general, the test environments are found to influence significantly the fatigue and corrosion fatigue behavior of material, especially at low frequencies. At a low frequency, much more time is available for a corrosion mechanism than fatigue at a high frequency. The tests were carried out at a low frequency, generally lower than $1 \mathrm{~Hz}$. Corrosive environment can cause higher crack growth rates than in dry air. In the fatigue mode of failure, crack will form, propagate and eventually rupture will occur. So there are three stages in fatigue life: i) Crack initiation, ii) Crack propagation, iii) Failure.

Raghava et al. [2] conducted fatigue crack growth studies on ESE(T) specimens made of IS 2062 Gr. E 300 steel in air and $3.5 \% \mathrm{NaCl}$ aqueous environment. The corrosion fatigue crack growth studies were carried out at different levels of corrosion current by applying constant direct current. The test frequency was maintained in the range of $0.25 \mathrm{~Hz}$ to 0.75 $\mathrm{Hz}$. The stress ratio was 0.1 . Significant increase in crack growth rate was observed with the increase of corrosion current. At test frequencies of $1 \mathrm{~Hz}$ and above, not much difference was observed in the results of fatigue crack growth studies in inert and corrosion environments. Chinnaiah et al. [3] observed the corrosion fatigue crack growth behavior of a $\mathrm{Ni}$ $\mathrm{Cr}-\mathrm{Mn}$ steel in $3.5 \% \mathrm{NaCl}$ saturated solution using $\mathrm{C}(\mathrm{T})$ specimens. Fatigue crack growth rate was higher and threshold stress intensities were lower in aqueous environment when compared to the lab air environment. It was also observed that the crack growth rate increased at lower frequencies and at higher stress ratio. Dong-Hwan Kang et al. [4] investigated fatigue and corrosion fatigue crack propagation behaviors of high-strength steel, HSB800 in air and 3.5\% $\mathrm{NaCl}$ aqueous environment using single-edge notched bending (SENB) specimens. The corrosion fatigue crack propagation rates in a seawater environment were higher than those in air environment. However, $\Delta K_{\text {th }}$ and $K_{\text {crit }}$ values were not so much changed according to environmental change. Meanwhile, simultaneously increasing $R$ and $f$ lead especially increase of $\Delta K t h$. Lin weng et al. [5] conducted CFCG experiments in dry air, distilled water and $3.5 \% \mathrm{NaCl}$ aqueous solution using precracked $\mathrm{C}(\mathrm{T})$ specimens. It was observed that the $\mathrm{CFCG}$ rate was effected by a pronounced $R$-ratio in $3.5 \% \mathrm{NaCl}$ aqueous solution. The higher the $R$-ratio the greater the crack growth velocity. This behavior held until the curves merge together with fatigue crack growth curves in air.

In the present work, fatigue crack growth study was carried out on ESE(T) specimen made of IS 2062 steel in corrosion environment. The corrosion environment was 3.5\% $\mathrm{NaCl}$ solution and corrosion process was accelerated by applying constant direct current (DC) of $0.2 \mathrm{~A}$. The FCG test was carried out by using a computer controlled servo-hydraulic fatigue rated Universal Testing Machine (UTM) of $\pm 250 \mathrm{kN}$ capacity under constant amplitude sinusoidal cyclic loading. The maximum and minimum load values were $15 \mathrm{kN}$ and 1.5 $\mathrm{kN}$. The test frequency was $0.375 \mathrm{~Hz}$ and the stress ratio was maintained as 0.1 . Crack growth data were recorded at regular intervals of fatigue loading cycles. Data obtained during the 
experiment have been discussed and crack growth curves were plotted. Using crack growth curves material constants $C$ and $m$ were found. Stress intensity factor range values were found and compared with analytical results.

\section{MATERIAL PROPERTIES}

The steel used in the present study is a high tensile structural steel suitable for general engineering purposes and suitable for all types of connections - welded, bolted and riveted conforming to IS $2062-2011$ [8]. Chemical analysis was done to find the chemical composition of the material. Table 1 gives the chemical composition of the steel and the specified values of various constituents as per IS 2062. Mechanical properties of the material were determined by carrying out tension tests as per ASTM E 8M - 11 [9]. Table 2 gives the mechanical properties of the steel and it satisfies the requirements of Grade E300 (Fe 440) of IS 2062.

\begin{tabular}{|c|c|c|}
\hline Composition & $\begin{array}{c}\text { Tested } \\
\text { values } \\
\mathbf{( \% )}\end{array}$ & $\begin{array}{c}\text { Specified (max) } \\
\text { (as per IS 2062:2011) } \\
\mathbf{( \% )}\end{array}$ \\
\hline Carbon & 0.13 & 0.20 \\
\hline Manganese & 1.10 & 1.5 \\
\hline Phosphorus & 0.034 & 0.045 \\
\hline Sulphur & 0.038 & 0.045 \\
\hline Silicon & 0.03 & 0.45 \\
\hline
\end{tabular}

Table 1. Chemical Composition of Steel

\begin{tabular}{|c|c|c|}
\hline Properties & $\begin{array}{c}\text { Tested } \\
\text { values } \\
(\%)\end{array}$ & $\begin{array}{c}\text { Specified (min) } \\
\text { (as per IS } \\
\mathbf{2 0 6 2 : 2 0 1 1 )} \\
\text { (\%) }\end{array}$ \\
\hline $\begin{array}{c}\text { Tensile strength, } \sigma_{u} \\
(\mathrm{MPa})\end{array}$ & 468 & 440 \\
\hline $\begin{array}{c}\text { Yield strength, } \sigma_{y} \\
(\mathrm{MPa})\end{array}$ & 306 & 300 \\
\hline$\%$ Elongation & 31.5 & 22 \\
\hline $\begin{array}{c}\text { Young's modulus, } E \\
(\mathrm{GPa})\end{array}$ & 200 & - \\
\hline
\end{tabular}

Table 2. Mechanical Properties of Steel

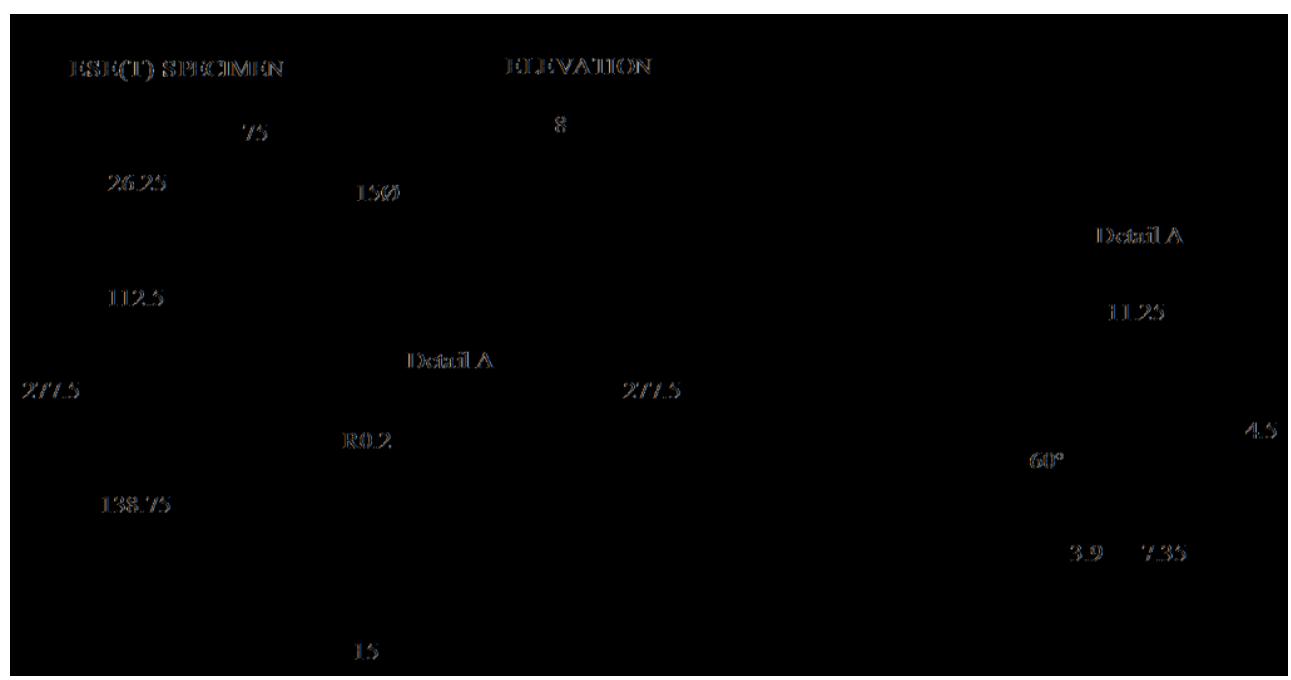

All dimensions are in $\mathrm{mm}$. 
Figure 2. Details of the specimen

\section{CORROSION RATE CALCULATION}

According to ASTM G102 - 2010 [11] the corrosion current density and corrosion rate were calculated and the corresponding values were $2500 \mu \mathrm{A} / \mathrm{cm}^{2}$ and $28.669 \mathrm{~mm} / \mathrm{yr}$. Table 3 gives the corrosion rate.

Faraday's Law can be used to calculate the corrosion rate

$C R=K_{1} \frac{i_{\text {cor }}}{\rho} E W$

where,

$$
\begin{aligned}
C R & =\text { corrosion rate }(\mathrm{mm} / \mathrm{yr}) \\
i_{\text {cor }} & =\text { corrosion density }\left(\mu \mathrm{A} / \mathrm{cm}^{2}\right) \\
K_{1} & =3.27 \times 10^{-3}, \mathrm{~mm} \mathrm{~g} / \mu \mathrm{A} \mathrm{cm} \mathrm{yr} \\
\rho & =\text { density }\left(\mathrm{g} / \mathrm{cm}^{3}\right)
\end{aligned}
$$

Table 3. Corrosion rate

\begin{tabular}{|c|c|c|c|c|}
\hline $\begin{array}{c}\text { Specimen } \\
\text { ID }\end{array}$ & $\begin{array}{c}\text { Corrosion } \\
\text { current } \\
\text { (A) }\end{array}$ & $\begin{array}{c}\text { Current } \\
\text { density, } \\
\boldsymbol{i}_{\text {cor }} \\
\left(\boldsymbol{\mu} \mathbf{A} / \mathbf{c m}^{2}\right)\end{array}$ & $\boldsymbol{E W}$ & $\begin{array}{c}\text { Corrosion } \\
\text { Rate } \\
(\mathbf{m m} / \mathbf{y r})\end{array}$ \\
\hline $\begin{array}{c}\text { IS- } \\
\text { CFCG8-4 } \\
\text { AC }\end{array}$ & 0.2 & 2500 & 27.53 & 28.669 \\
\hline
\end{tabular}

\section{EXPERIMENTAL STUDY}

The fatigue crack growth experiment was conducted using a of $\pm 250 \mathrm{kN}$ capacity computer controlled servohydraulic fatigue rated Universal Testing Machine (UTM). For carrying out CFCG tests it was required to provide a corrosion environment surrounding the notch. A chamber made of 'Perspex' sheet containing 3.5\% sodium chloride solution, was fixed around the notch which acted as corrosion environment. The water level in the chamber was kept at $30 \mathrm{~mm}$ below the notch and $15 \mathrm{~mm}$ above the notch. The same level of $45 \mathrm{~mm}$ was maintained throughout the test because the exposed area of specimen in corrosion environment should not be varied. The corrosion process was accelerated by increasing the corrosion current which was supplied by a Regulated Power Supply (RPS). The test was conducted at corrosion current of $0.2 \mathrm{~A}$ and the test frequency was $0.375 \mathrm{~Hz}$. The stress ratio was maintained as 0.1

For the test, the maximum and minimum load values were $15.0 \mathrm{kN}$ and $1.5 \mathrm{kN}$. The maximum load of the specimen was determined by following equation as per ASTM E 1820 11 [12].

$P_{m}=\frac{0.4 B b_{o}^{2} \sigma_{Y}}{\left(2 W+a_{o}\right)}$

Where,

$$
\begin{aligned}
B & =\text { thickness of the specimen, } \mathrm{mm} \\
W & =\text { width of the specimen, } \mathrm{mm} \\
a_{0} & =\text { initial notch length, } \mathrm{mm} \\
b_{0} & =\text { uncracked ligament }=W-a_{0}, \mathrm{~mm} \\
\sigma_{y} & =\text { yield strength of the material, } \mathrm{MPa}
\end{aligned}
$$

Table 4 gives details of FCG tests. At regular intervals the corrosive medium was removed and crack growth data was recorded. Number of cycles for crack initiation and crack propagation were recorded for specimen. The experiment was continued till crack growth in the specimen became unstable.
Table 4. Details of FCG Tests

\begin{tabular}{|c|c|c|c|}
\hline Specimen ID & $\begin{array}{c}\text { Frequency } \\
\text { (Hz) }\end{array}$ & $\begin{array}{c}\text { Stress } \\
\text { ratio, } \boldsymbol{R}\end{array}$ & $\begin{array}{c}\text { Corrosion } \\
\text { Current } \\
\text { (A) }\end{array}$ \\
\hline IS-CFCG8-4 AC & 0.375 & 0.1 & 0.2 \\
\hline
\end{tabular}

Figure. 3 shows the experimental set-up. Figure. 4 shows the close-up view of the specimen and Fig. 5 shows the close-up view of the specimen after failure. For the FCG results to be valid, it is required that the specimen be predominantly elastic at all values of applied force. For the ESE(T) specimen the following has to be satisfied:

$$
(W-a) \geq(4 / \pi)\left(K_{\max } / \sigma_{Y S}\right)^{2}
$$

Where,

$$
\begin{aligned}
(W-a) & =\text { uncracked ligament } \\
\sigma_{Y S} & =\text { yield strength } \\
K_{\max } & =\text { maximum SIF }
\end{aligned}
$$

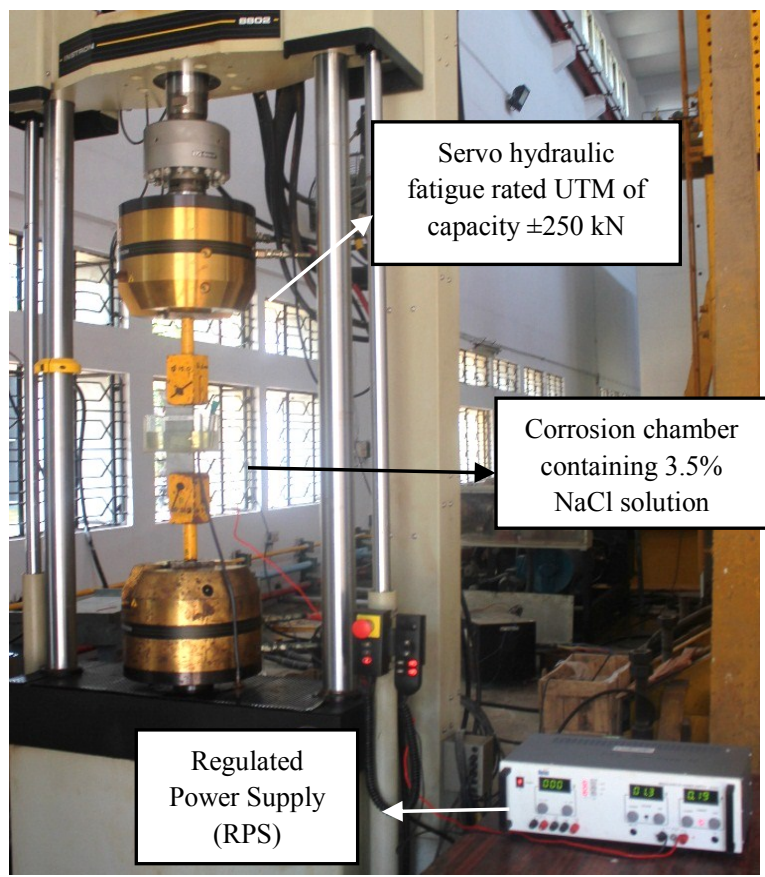

Figure 3. Experimental set-up 


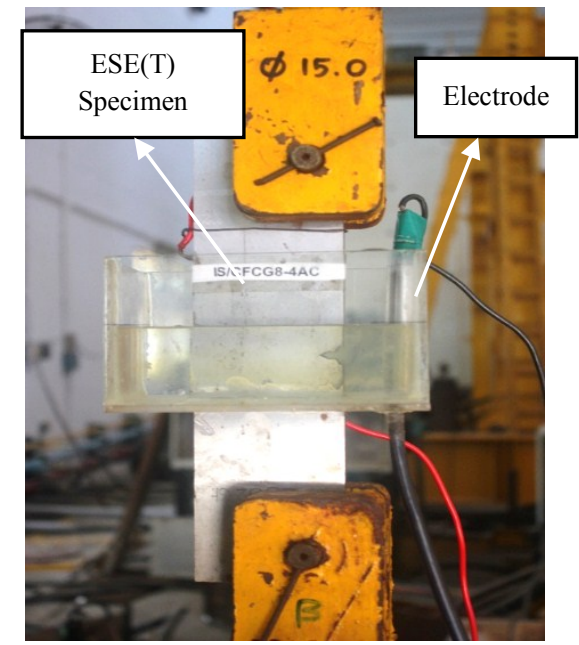

Figure 4. Close-up view of the specimen

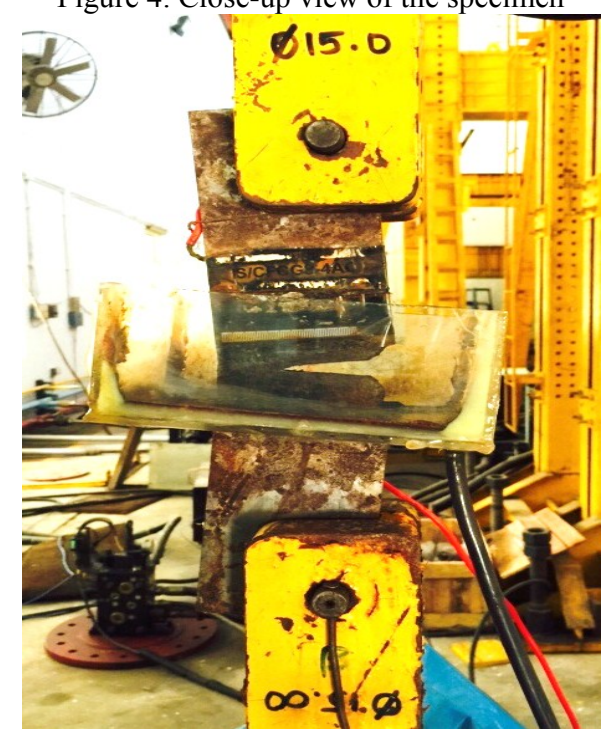

Figure 5. Close-up view of the specimen after failure

\section{COMPARISON OF $\triangle K$ VALUES}

According to the specifications of ASTM - 647 the stress intensity factors range for $\operatorname{ESE}(\mathrm{T})$ specimen were calculated. Using Abaqus, a finite element software models were created for different crack lengths. For different crack lengths the stress intensity factor range values were found. The values obtained from experiment and Abaqus were compared. Table 5 gives the comparison of values of stress intensity factor range.

Table 5. Comparison of $\Delta K$ Values

\section{RESULTS AND DISCUSSIONS}

Table 6 gives the details of crack initiation and growth till elastic limit and failure of the tested specimen. It also gives number of cycles at the end of experiment and the corresponding crack length including initial notch length. The test was terminated when the crack growth in the specimen became unstable and the uncracked ligament was insufficient to take further cyclic load. Figure. 6 shows images

\begin{tabular}{|c|c|c|}
\hline \multirow{2}{*}{$\begin{array}{c}\text { Crack } \\
\text { length } \\
(\mathbf{m m})\end{array}$} & $\begin{array}{r}\text { Stress intensity factor range, } \boldsymbol{\Delta K} \\
\mathbf{( M P a} / \sqrt{\mathbf{m})}\end{array}$ \\
\cline { 2 - 3 } & From experiment & From Abaqus* \\
\hline 11.25 & 13.273 & 8.97 \\
\hline 13.191 & 14.610 & 10.166 \\
\hline 15.566 & 16.295 & 11.460 \\
\hline 18.615 & 18.610 & 13.119 \\
\hline 20.595 & 20.245 & 14.287 \\
\hline 32.431 & 33.726 & 23.714 \\
\hline \multicolumn{2}{|c|}{$*$ - Effect of corrosion is not considered. } \\
\hline
\end{tabular}

at different stages of fatigue cycles for the specimen. The crack lengths were measured and plotted against the corresponding number of load cycles as shown in Fig. 7.

Figure. 8 shows the variation of fatigue crack growth rate with $\log$ stress intensity factor range. Based on this relation, the fatigue crack growth related material constants $C$ and $m$ were found.

Table 6. Results of FCG Tests 
International Journal of Science and Engineering Applications

Volume 4 Issue 3, 2015, ISSN-2319-7560 (Online)
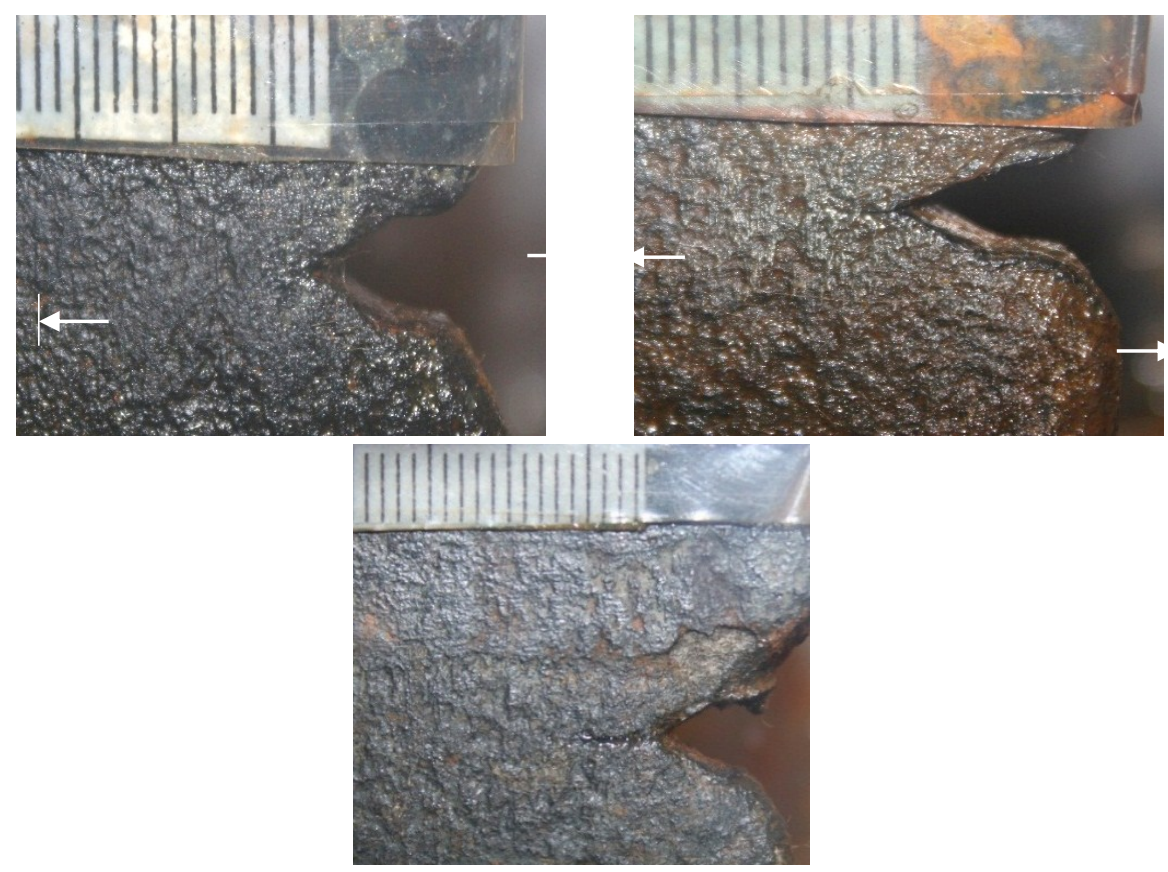

(a) 92000 cycles

Crack length: $1.348 \mathrm{~mm}$ (b) 114000 cycles

Crack length: $2.684 \mathrm{~mm}$ (c) 138000 cycles

Crack length: $4.954 \mathrm{~mm}$

\begin{tabular}{|c|c|c|c|c|c|c|}
\hline \multirow{2}{*}{ Specimen ID } & \multicolumn{2}{|c|}{ Crack initiation } & \multicolumn{2}{c|}{$\begin{array}{c}\text { Crack length } \\
\text { corresponding to elastic } \\
\text { limit }\end{array}$} & \multicolumn{2}{c|}{ End of experiment } \\
\cline { 2 - 7 } & $\begin{array}{c}\text { Number } \\
\text { of cycles }\end{array}$ & $\begin{array}{c}\text { Crack } \\
\text { length } \\
(\mathrm{mm})\end{array}$ & $\begin{array}{c}\text { Number } \\
\text { of cycles }\end{array}$ & $\begin{array}{c}\text { Crack } \\
\text { length* } \\
(\mathrm{mm})\end{array}$ & $\begin{array}{c}\text { Number } \\
\text { of cycles }\end{array}$ & $\begin{array}{c}\text { Crack } \\
\text { length* } \\
(\mathrm{mm})\end{array}$ \\
\hline IS-CFCG8-4 AC & 80000 & 0.279 & 204000 & 37.431 & 206476 & 45.302 \\
\hline \multicolumn{7}{|c|}{$*$ Including initial notch length of $11.25 \mathrm{~mm}$} \\
\hline
\end{tabular}

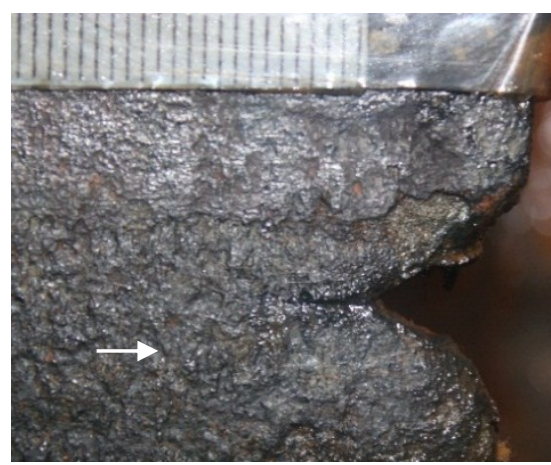

(d) 152000 cycles

Crack length: $5.837 \mathrm{~mm}$

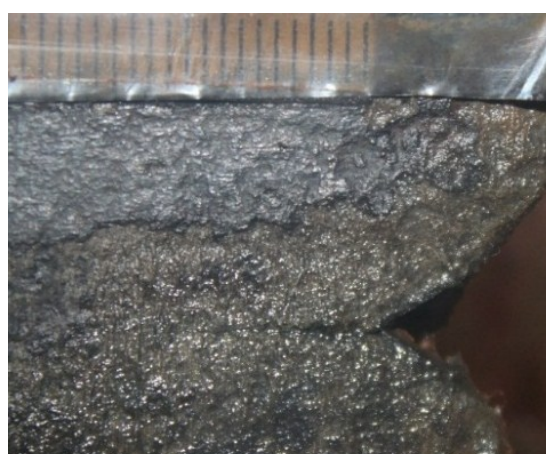

(e) 180000 cycles

Crack length: $10.234 \mathrm{~mm}$

Figure 6. Crack growth images of the specimen

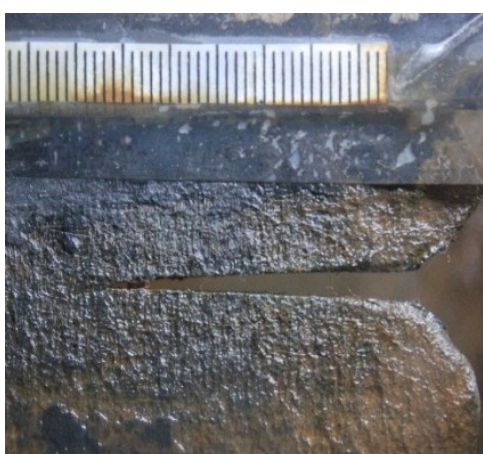

(f) 206000 cycles

Crack length: $31.03 \mathrm{~mm}$ 


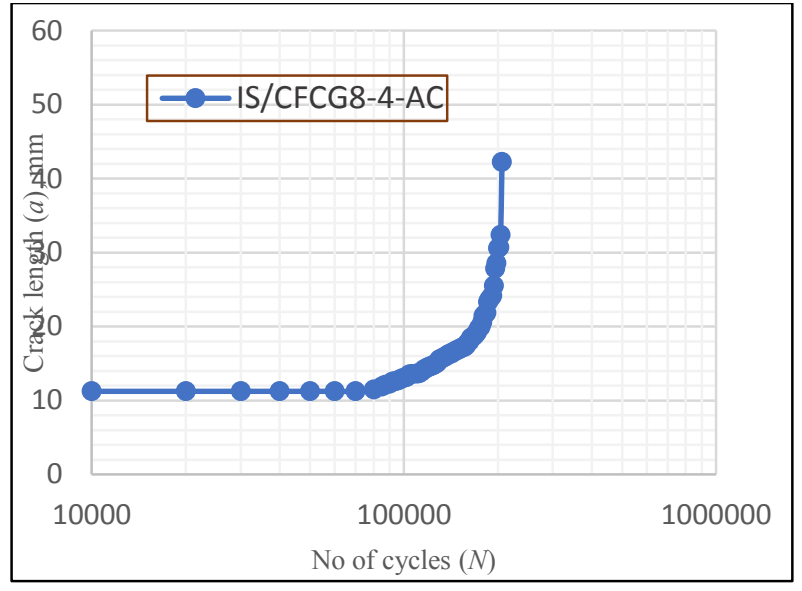

Figure 7. Crack length vs. number of cycles curves

Stress intensity factor range $(\Delta K)$ for different crack length values was computed using the expression given in ASTM E 647-11:

and

$$
\Delta K=\left[\frac{\Delta P}{B \sqrt{W}}\right] F
$$

where,

$$
\begin{gathered}
\Delta P=P_{\text {max }}-P_{\text {min }} \\
F=\alpha^{1 / 2}[1.4+\alpha][1-\alpha]^{-3 / 2} G
\end{gathered}
$$

$$
\begin{gathered}
G=3.97-10.88 \alpha+26.25 \alpha^{2}-38.9 \alpha^{3}+30.15 \alpha^{4}-9.27 \alpha^{5} \\
\alpha=a / W
\end{gathered}
$$

for $0<\alpha<1$

$W$ - width of the specimen

$B$ - thickness of the specimen

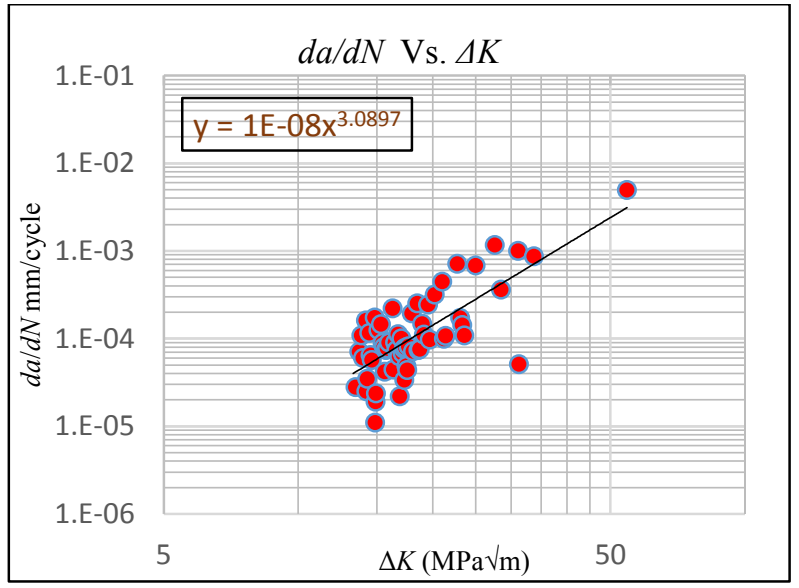

Figure 8. $d a / d N$ vs. $\Delta K$ curve

From the plot of $d a / d N$ vs. $\Delta K$ curve the following equation was obtained from which the corrosion crack growth constants were found. Table 7 gives the Paris constants.

$$
y=1 \times 10^{-8} x^{3.0897}
$$

$\underline{\text { www.ijsea.com }}$
Table 7. Corrosion Fatigue Crack Growth Parameters

\section{CONCLUSIONS}

Corrosion fatigue crack growth study was carried out on ESE(T) specimen of IS 2062 steel in corrosion environment. The test was conducted under constant amplitude loading by using a $\pm 250 \mathrm{kN}$ capacity fatigue rated UTM. The corrosion process was accelerated by applying a constant direct current of $0.2 \mathrm{~A}$. The loading frequency was $0.375 \mathrm{~Hz}$ and the stress ratio was maintained as 0.1 . Number of cycles to crack initiation was determined and corrosion fatigue crack growth rate was monitored. Based on the corrosion fatigue crack growth data, FCG parameters $C$ and $m$ were determined. The present experiment forms a part of the studies being carried out at CSIR-SERC to evolve an accelerated corrosion fatigue methodology to simulate real life corrosion fatigue damage.

\section{ACKNOWLEDGEMENTS}

The first author thanks the Director, CSIR-SERC for the opportunity provided to her to carry out her post-graduate project work at the Fatigue \& Fracture Laboratory, CSIRSERC. The assistance rendered by the technical staff of FFL, CSIR-SERC in conducting the experimental investigations is gratefully acknowledged. This paper is published with the kind

\begin{tabular}{|c|c|c|}
\hline Specimen ID & $\boldsymbol{C}$ & $\boldsymbol{m}$ \\
\hline IS-CFCG8-4-AC & $1 \times 10^{-8}$ & 3.0897 \\
\hline
\end{tabular}

permission of Director, CSIR-SERC.

\section{REFERENCES}

[1] G. Raghava, "Fatigue and fracture investigations on structural components and materials", Advanced Course on Fatigue and Fracture Behaviour of Materials, Components and Structures, CSIR SERC, Chennai (2009), Sigma Publications, Chennai, pp. 203-229

[2] G. Raghava, P. Gandhi and A.G. Madhava Rao, "Corrosion fatigue in offshore structural steels - A review", International Symposium on Fatigue and Fracture in Steel and Concrete Structures, Madras, 1991, pp. 759-776

[3] Chinnaiah Madduri, and Raghu V Prakash, "Corrosion Fatigue Crack Growth Studies in $\mathrm{Ni}-\mathrm{Cr}$ Mn Steel", International Journal of Mechanical and Materials Engineering 1 (2010) pp. 20-25

[4] Dong Hwan Kang, Jong-Kwan Lee and Tae-Won Lee, "Corrosion fatigue crack propagation in a heat affected zone of high performance steel in an underwater sea environment", Engineering Failure Analysis, 18 (2011), pp. 557-563

[5] Lin Weng, Jixi Zhang, Sergiy Kalnaus, Miaoling Feng and Yanyao Jiang "Corrosion fatigue crack growth of AISI 4340 steel”, International Journal of Fatigue 48 (2013), pp. 156-164

[6] S. Sivaprasad, S. Tarafder, V.R. Ranganath, M. Tarafder and K.K. Ray, "Corrosion fatigue crack growth behaviour of naval steels", Corrosion Science, 48 (2006), pp. 1996-2013.

[7] Thierry Palin-Luc, Rubén Pérez-Mora,Claude Bathias, Gonzalo Domínguez, Paul C. Paris and Jose Luis Arana "Fatigue crack initiation and growth on a steel in the very high cycle regime with sea water 
International Journal of Science and Engineering Applications

Volume 4 Issue 3, 2015, ISSN-2319-7560 (Online)

corrosion", Engineering Fracture Mechanics, 77 (2010) pp. 1953-1962

[8] IS 2062: 2011, "Hot rolled low-, medium and high tensile structural steel”, Bureau of Indian Standards, New Delhi.

[9] ASTM E 8M - 2011, "Standard test methods for tension testing of metallic materials", ASTM International, USA.

[10] ASTM E 647 - 2013, "Standard test method for measurement of fatigue crack growth rates, ASTM International, USA.

[11] ASTM G 102 - 1989, "Standard practice for calculation of corrosion rates and related information from electrochemical measurements", ASTM International, USA.

[12] ASTM E 1820 - 2011, "Standard test method for measurement of fracture toughness, ASTM International, USA.

[13] M.A. Wahab and M. Sakano, "Experimental study of corrosion fatigue behaviour of welded steel structures", Journal of Materials Processing Technology, 118 (2001), pp. 117-122 